\title{
Lanreotide and octreotide complexed with technetium-99m: labeling, stability and biodistribution studies
}

\author{
Bluma Linkowski Faintuch1*, Nilda Petrona Sosa Pereira', Salomão Faintuch², Emiko Muramoto1', \\ Constancia Pagano Gonçalves Silva ${ }^{1}$
}

${ }^{1}$ Centro de Radiofarmácia - Instituto de Pesquisas Energéticas e Nucleares (IPEN/CNEN), ${ }^{2}$ Departamento de Radiologia - Universidade Federal de S. Paulo - Escola Paulista de Medicina.

*Correspondence:

B. L. Faintuch

Instituto de Pesquisas Energéticas e

Nucleares (IPEN/CNEN)

Centro de Radiofarmácia

Av. Prof. Lineu Prestes, 2242 - Cidade

Universitária

05508-900 - São Paulo - SP, Brazil

E-mail: faintuch@net.ipen.br
Lanreotide and Octreotide are cyclic octapeptide analogues of somatostatin that were labeled with the radioisotope Technetium$99 \mathrm{~m}$ for use in diagnostic nuclear medicine. The peptides were processed in a tartrate/phthalate buffer solution containing reducing agent. The purpose of this investigation was to optimize direct labeling by varying some parameters, and to evaluate radiochemical stability and biodistribution in animals. The marked peptides were obtained with high labeling efficiency and no need for subsequent purification. Best radiolabeling results corresponded to a molar ratio of $\mathrm{SnCl}_{2} \cdot \mathrm{H}_{2} \mathrm{O} /$ peptide of $4.5 .{ }^{99 m} \mathrm{Tc}$-peptides were radiochemically stable for 6 hours. ${ }^{99 m} T c$-octreotide was relatively more susceptible to cysteine challenge than ${ }^{99 m} T c$-lanreotide. ${ }^{99 m} T c$ peptides were mainly distributed in the gastrointestinal tract but ${ }^{99 m} \mathrm{Tc}$-lanreotide showed a greater uptake by the liver than ${ }^{99 m} \mathrm{Tc}$ octreotide. Results indicated that the products can be obtained with high radiochemical yield, in a simple routine appropriate for further studies to assess their efficacy in radiodiagnosis.
Uniterms

- Technetium

- Radiolabeling

- Peptides

- Somatostatin

- Octreotide

- Lanreotide

\section{INTRODUCTION}

In a very short period of time radiolabeled peptides have become an important class of imaging agents for detection not only of tumors but also of thrombosis and infection/inflammation (Van Der Laken et al., 2000; Rennen et al., 2001). Somatostatin (SST) is a multifunctional peptide that is synthesized in neuroendocrine and other cells present in many tissues and organs including central and peripheral nervous system, gastrointestinal tract, endocrine pancreas, thyroid, adrenals, genitourinary tract and lymphatic tissue. There are a number of somastostatin-related radiopharmaceuticals available today, especially for visualization of neuroendocrine tumours (Angetti et al., 1998; Leners et al., 1996; Oppizi et al., 1998; Signore et al., 1995).

The first clinical research using radiolabeled somatostatin analogues was performed by Lamberts et al. (1990). Historically, somatostatin analogs were the first class of receptor-binding peptides to gain clinical application. Lamberts et al. (1990) used ${ }^{123}{\mathrm{I}-\mathrm{Tyr}^{3} \text {-octreo }}$ tide to localize somatostatin receptor-bearing tumors. 
However this product showed some disadvantages in clinical practice such as limited availability, high cost and high intestinal radioactivity due to hepatobiliary clearance (Krenning et al., 1992). Consequently a new tracer was developed, namely ${ }^{111}$ In-DTPA-octreotide (Octreoscan-Mallinckrodt Inc.), that displayed high sensitivity for diagnosis of both primary and metastatic tumor lesions.

${ }^{111}$ In-DTPA-[D-Phe ${ }^{1}$-octreotide is the first radiopeptide which has obtained regulatory approval in Europe and the United States. Although Octreoscan is widely used for imaging somatostatin receptors, the use of ${ }^{111}$ In imposes some limitations, due to its suboptimal imaging characteristics, high cost and limited availability. As far as diagnostic imaging is concerned, technetium$99 \mathrm{~m}$ continues to be the most widely used radionuclide. ${ }^{99 \mathrm{~m}} \mathrm{Tc}-$-Apcitide and ${ }^{99 \mathrm{~m}} \mathrm{Tc}-\mathrm{Depreotide}$ also received regulatory approval. The former is used for acute thrombosis and the latter is used for the differentiation between benign lesions and pulmonary neoplasia, based on expression of somatostatin receptors (Weiner et al., 2002).

Technetium-99m has been used in the last decade to label many kits. Its nuclear features of 6-hour half-life and gamma energy of $140 \mathrm{keV}$ make it one of the best radionuclides as regards imaging qualities, with a halftime long enough to permit complete studies without an unnecessary dose of radiation. It is easily available by elution in isotonic saline from a ${ }^{99} \mathrm{Mo} /{ }^{99 \mathrm{~m}} \mathrm{Tc}$ generator.

The challenge of radiolabeling is to obtain a complex that maintains the biological activity of the peptide. ${ }^{99 \mathrm{~m}} \mathrm{Tc}$ labeling of somatostatin analogues has been extensively studied, including attempts at direct labeling after reduction of the disulfide bridge (Kolan et al., 1996; Haberberger et al., 1995; Thakur et al., 1996) and the use of bifunctional chelates (Hnatowich et al., 1998; Baidoo et al., 1998).

Lanreotide [D-(Nal-Cys-Tyr-D-Trp-Lys-Val-CysThr. $\left.\mathrm{NH}_{2}\right]$ as well as octreotide $\left[\mathrm{H}_{2} \mathrm{~N}-\mathrm{D}\right.$-Phe-Cys-Phe-DTrp-Lys-Thr-Cys-Thr(OH)] are synthetic octapeptide analogs of the native hormone somatostatin, produced by the hypothalamus and pancreas (Smith-Jones et al., 1999). They are cyclized via cysteine bridge.

Lanreotide and octreotide are widely used for the symptomatic treatment of neuroendocrine-active tumors, such as growth hormone-producing pituitary adenomas and gastroenteropancreatic tumors (Arnold et al., 2000).

Preparation of ${ }^{99 \mathrm{~m}} \mathrm{Tc}$-labeled octapeptides, namely octreotide and lanreotide, analysis of their radiochemical purity and stability, as well as the biodistribution pattern in animals were the aims of the current investigation.

\section{MATERIAL AND METHODS}

\section{Material}

Lanreotide 8-mer was obtained from Pi-Chem (Graz, Austria) provided by the International Atomic Energy Agency (IAEA) and octreotide was a generous gift of Novartis (São Paulo, Brazil). Technetium-99m was obtained from an alumina-based ${ }^{99} \mathrm{Mo} /{ }^{99 \mathrm{~m}} \mathrm{Tc}$ generator locally supplied by Institute of Energetic and Nuclear Research (IPEN/CNEN) - São Paulo, Brazil.

\section{Methods}

\section{Preparation of Peptides}

Each preparation and labeling procedure was identical for both peptides and all solutions were nitrogenpurged. In brief, $2.5 \mathrm{mg}$ of the peptide was dissolved in water and distributed in many vials in different samples (10 to $100 \mathrm{mg}$ ) that were frozen at $-30{ }^{\circ} \mathrm{C}$ until use. To a vial containing the peptide a small volume of a solution containing $20 \mathrm{mM}$ tartrate, $80 \mathrm{mM}$ phthalate, $4 \%$ maltose, and $100 \mathrm{mM}$ glycine was added. A solution of stannous chloride in $\mathrm{HCl} 0.1 \mathrm{~N}$ based on the defined molar ratio of $\mathrm{SnCl}_{2} \cdot 2 \mathrm{H}_{2} 0 /$ peptide was also introduced in the mixture.

After allowing the preparation to react at room temperature for $4 \mathrm{~h}$ with continuous rotation, the resulting solution was stored frozen at $-30{ }^{\circ} \mathrm{C}$ until use or immediately labeled.

\section{Radiolabeling}

${ }^{99 \mathrm{~m}} \mathrm{Tc}$ was obtained from the column of the generator by elution with $6 \mathrm{ml}$ of $0.9 \%$ sodium chloride injection. ${ }^{99 \mathrm{~m}} \mathrm{Tc}$ (37-370 MBq) was added to the peptide mixture prepared as above. The solution was heated for 15 minutes in a water bath at $100{ }^{\circ} \mathrm{C}$ and then left at room temperature to cool.

\section{Radiochemical Control}

Radiochemical analysis of ${ }^{99 \mathrm{~m}} \mathrm{Tc}$-peptides was performed by thin-layer chromatography (TLC) to determine labeling efficiency and colloid formation. Instant Thin Layer Chromatography - Silica Gel (ITLC-SG) chromatography paper was cut into $1.5 \mathrm{x} 13 \mathrm{~cm}$ strips and activated by heating for $30 \mathrm{~min}$, at $110^{\circ} \mathrm{C}$, according to the manufacturer instructions.

Labeling efficiency was determined using acidified ethanol $85 \%$ and saline $0.9 \%$ as the mobile phase. The radioactivity of the strips was analyzed in radiochromatography equipment (Berthold, Belgium). 


\section{Optimization of Radiolabeling}

Optimization was achieved by varying parameters including peptide mass $(10,50,100 \mathrm{mg})$, stannous chloride/peptide molar ratio $(1.8,2.7,3.6,4.5)$ and reaction time ( 0.5 and 1.0 hour). Radiochemical stability of the complex was observed until 6 hours.

\section{Cysteine Challenge}

Bond strength of ${ }^{99 \mathrm{~m}} \mathrm{Tc}$ peptide complexes was evaluated by displacement of bound radionuclide with cysteine (Rhodes et al., 1995). Known amounts of ${ }^{99 \mathrm{~m}} \mathrm{Tc}-$ lanreotide and ${ }^{99 \mathrm{~m}} \mathrm{Tc}$-octreotide were challenged over a range of cysteine concentrations $(0.1 \mathrm{mM}$ to $100 \mathrm{mM})$ at $37^{\circ} \mathrm{C}$ for 1 hour. The percentage of ${ }^{99 \mathrm{~m}} \mathrm{Tc}$ displaced by cysteine was determined by TLC using $0.9 \%$ saline as mobile phase, and the amount of displaced radiolabel found at the solvent front was determined.

\section{Biodistribution studies}

Experiments were carried out in compliance with the guidelines for conduct in animal experimentation, Scientific Ethics Committee, IPEN/CNEN-SP.

Invasive biodistribution assessment was done in groups of six Swiss mice by intravenous injection of 0.1 $\mathrm{ml}$ of radiolabeled peptides with $3.7 \mathrm{MBq}$ of ${ }^{99 \mathrm{~m}} \mathrm{Tc}$. Animals were sacrificed after injection and organs were removed, weighed and radioactivity was determined in a well-type gamma counter. Radioactivity was also measured in blood samples. The results were expressed as percentage of injected dose per gram of tissue.
Dynamic imaging studies were performed in Wistar rats (4 animals/group) at the first 10 minutes of administration of each drug and static imaging after 15 min, 2, 4 and 6 hours post injection.

\section{RESULTS}

\section{Peptide labeling with technetium-99m by direct method}

Labeling efficiency determined by thin-layer chromatography with $0.9 \%$ saline as a mobile phase showed that unbound radioactivity migrated with the solvent front, while bound radioactivity remained at the origin (Figure 1).

Amount of colloids formed in the peptide solution was determined using $85 \%$ ethanol as a mobile phase. Radiolabeled peptides moved to the solvent front and colloids remained at the origin (Figure 2).

The first study with ${ }^{99 \mathrm{~m} T c}$ was made varying the amount of stannous chloride in the labeling of octreotide in tartrate/phtalate buffer solution (Figure 3).

It had been previously observed that with $10 \mathrm{mg}$ of $\mathrm{SnCl}_{2} \cdot \mathrm{H}_{2} \mathrm{O}$ the peptide was not labeled. The amount was insufficient to reduce cysteine bridges and technetium, so the reaction did not occur.

When the molar ratio between reducing agent and peptide (octreotide) was low the resulting yield was also low. The best finding was for a molar ratio of 4.5 (Table I).

Labeling of lanreotide with ${ }^{99 \mathrm{~m}} \mathrm{Tc}$ was investigated on the basis of the results obtained with ${ }^{99 \mathrm{~m}} \mathrm{Tc}$-octreotide.



FIGURE 1 - Radiochromatogram of ${ }^{99 m}$ Tc-lanreotide in saline $0.9 \%$. 




FIGURE 2 - Radiochromatogram of ${ }^{99 \mathrm{~m}} \mathrm{Tc}$-lanreotide in ethanol $85 \%$ as solvent.



FIGURE 3 - Labeling efficiency of ${ }^{99 \mathrm{~m}}$ Tc-octreotide.

TABLE 1 - Radiochemical purity of ${ }^{99 m}$ Tc-octreotide varying the molar ratio of $\mathrm{SnCl}_{2} \cdot \mathrm{H}_{2} \mathrm{O}$ /octreotide

\begin{tabular}{|c|c|c|c|}
\hline $\mathrm{SnCl}_{2} \cdot \mathrm{H}_{2} \mathrm{O} /$ octreotide & $\%{ }^{99 \mathrm{~m}} \mathrm{TcO}_{4}$ & $\%{ }^{99 \mathrm{~m}} \mathrm{TcO}_{2}$ & $\%{ }^{99 m}$ Tc-octreotide \\
\hline 1.8 & $91.0 \pm 0.4$ & $2.9 \pm 0.3$ & $6.0 \pm 0.8$ \\
\hline 2.7 & $30.5 \pm 1.1$ & $1.9 \pm 0.6$ & $67.6 \pm 1.6$ \\
\hline 3.6 & $48.9 \pm 1.9$ & $1.0 \pm 0.3$ & $50.1 \pm 2.3$ \\
\hline 4.5 & $3.5 \pm 1.9$ & $1.4 \pm 0.1$ & $95.1 \pm 2.0$ \\
\hline
\end{tabular}

Octreotide $=50 \mu \mathrm{g}$ 
So, we observed that the best molar ratio between $\mathrm{SnCl}_{2} \cdot \mathrm{H}_{2} 0.2 \mathrm{H}_{2} \mathrm{O} /$ lanreotide was 4.9 for a mass of lanreotide and a mass of stannous chloride above $50 \mathrm{mg}$ (Figure 4).

Both ${ }^{99 \mathrm{~m}} \mathrm{Tc}$-octreotide or ${ }^{99 \mathrm{~m}} \mathrm{Tc}$-lanreotide were radiochemically stable for 6 hours (Table 2). However ${ }^{99 \mathrm{~m}} \mathrm{Tc}$-octreotide had a loss in radiochemical purity of $3.9 \%$.

Transchelation to cysteine was studied at five molar ratios (Figure 5). It was observed that ${ }^{99 m} \mathrm{Tc}$-octreotide was relatively more susceptible to Cys challenge than ${ }^{99 \mathrm{~m}} \mathrm{Tc}-$ lanreotide.
TABLE 2 - Radiochemical stability. Tested amounts were: for $\mathrm{m}_{\text {lanreotide }}, 50 \mu \mathrm{g}$; for $\mathrm{m}_{\text {octreotide }}, 50 \mu \mathrm{g}$ and for $\mathrm{m}_{\mathrm{SnCl} 2.2 \mathrm{H} 2 \mathrm{O}}$ also $50 \mu \mathrm{g}$

\begin{tabular}{ccc}
\hline $\begin{array}{c}\text { Time } \\
\text { (hours) }\end{array}$ & $\begin{array}{c}\text { \% Radiochemical } \\
\text { Purity } \\
\text { 99m Tc-octreotide }\end{array}$ & $\begin{array}{c}\text { \% Radiochemical } \\
\text { Purity } \\
{ }^{\text {99m }} \text { Tc-lanreotide }\end{array}$ \\
\hline 0 & $95.1 \pm 2.0$ & $97.9 \pm 0.9$ \\
2 & $92.1 \pm 1.0$ & $96.2 \pm 1.7$ \\
4 & $95.9 \pm 0.6$ & $97.3 \pm 0.8$ \\
6 & $91.2 \pm 0.3$ & $96.7 \pm 1.3$ \\
\hline
\end{tabular}

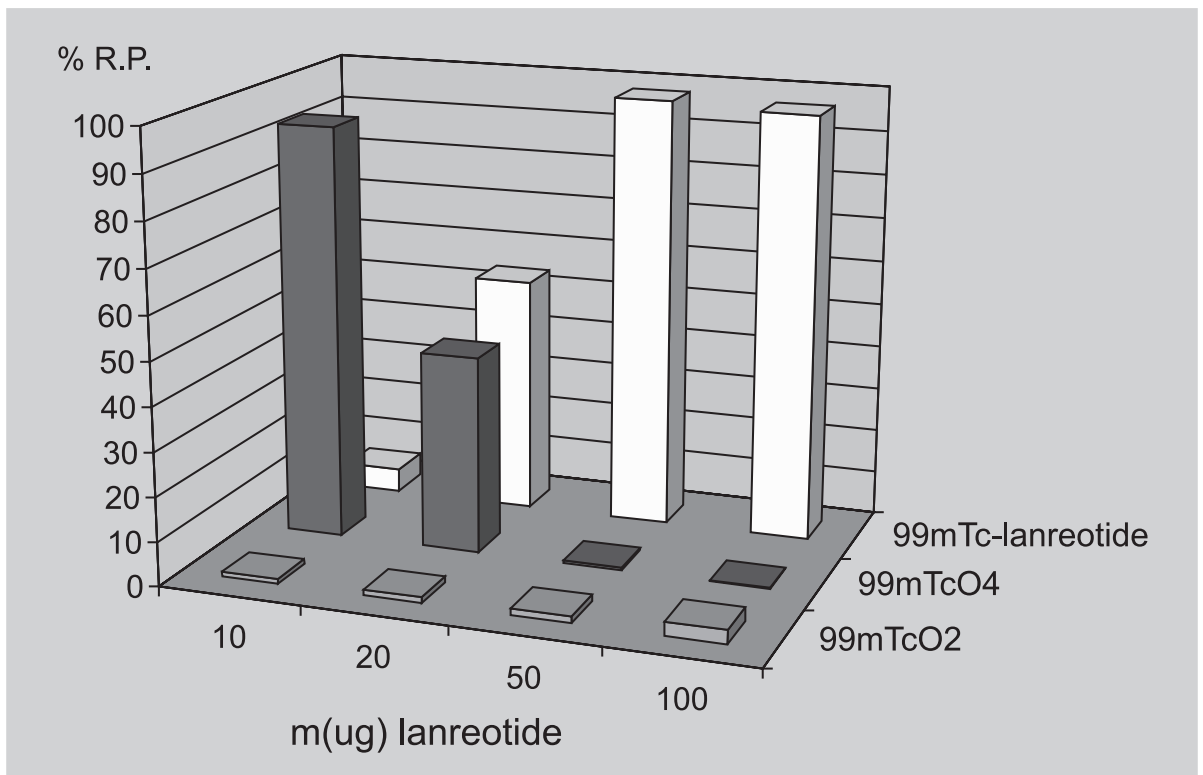

FIGURE 4 - Radiochemical efficiency of ${ }^{99 m}$ Tc-lanreotide.

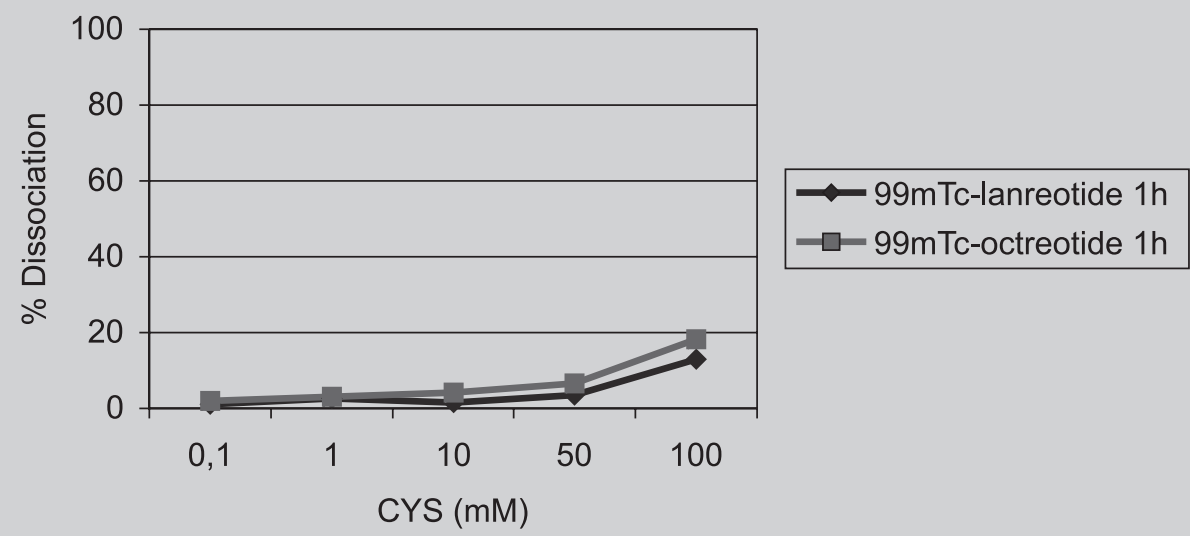

FIGURE 5 - Percent dissociation of ${ }^{99 \mathrm{~m}} \mathrm{Tc}$ from the peptides vs. Cys concentration. 
Biodistribution of ${ }^{99 m}$ Tc-labeled peptides

Preliminary biodistribution of ${ }^{99 \mathrm{~m}} \mathrm{Tc}$-lanreotide and ${ }^{99 \mathrm{~m}} \mathrm{Tc}$-octreotide was assessed in normal Wistar rats by dynamic imaging techniques during the first 10 minutes after injection (Figure 6) and by static imaging at $15 \mathrm{~min}$ (Figure 7), 1, 2 and 4 hours post injection. No differences were observed, in static images, among these times.
Invasive studies were done in Swiss mice and the results can be observed in Figure 8 and Figure $9 .{ }^{99 \mathrm{~m}} \mathrm{Tc}-$ labeled peptides localized in the gastrointestinal tract or in the kidney. For ${ }^{99 \mathrm{~m}} \mathrm{Tc}$-octreotide the greatest uptake corresponded to small intestine and kidneys (Figure 8). ${ }^{99 \mathrm{~m}}$ Tc-lanreotide exhibited highest affinity for the liver in the first 15 min post injection, and no clearance of blood

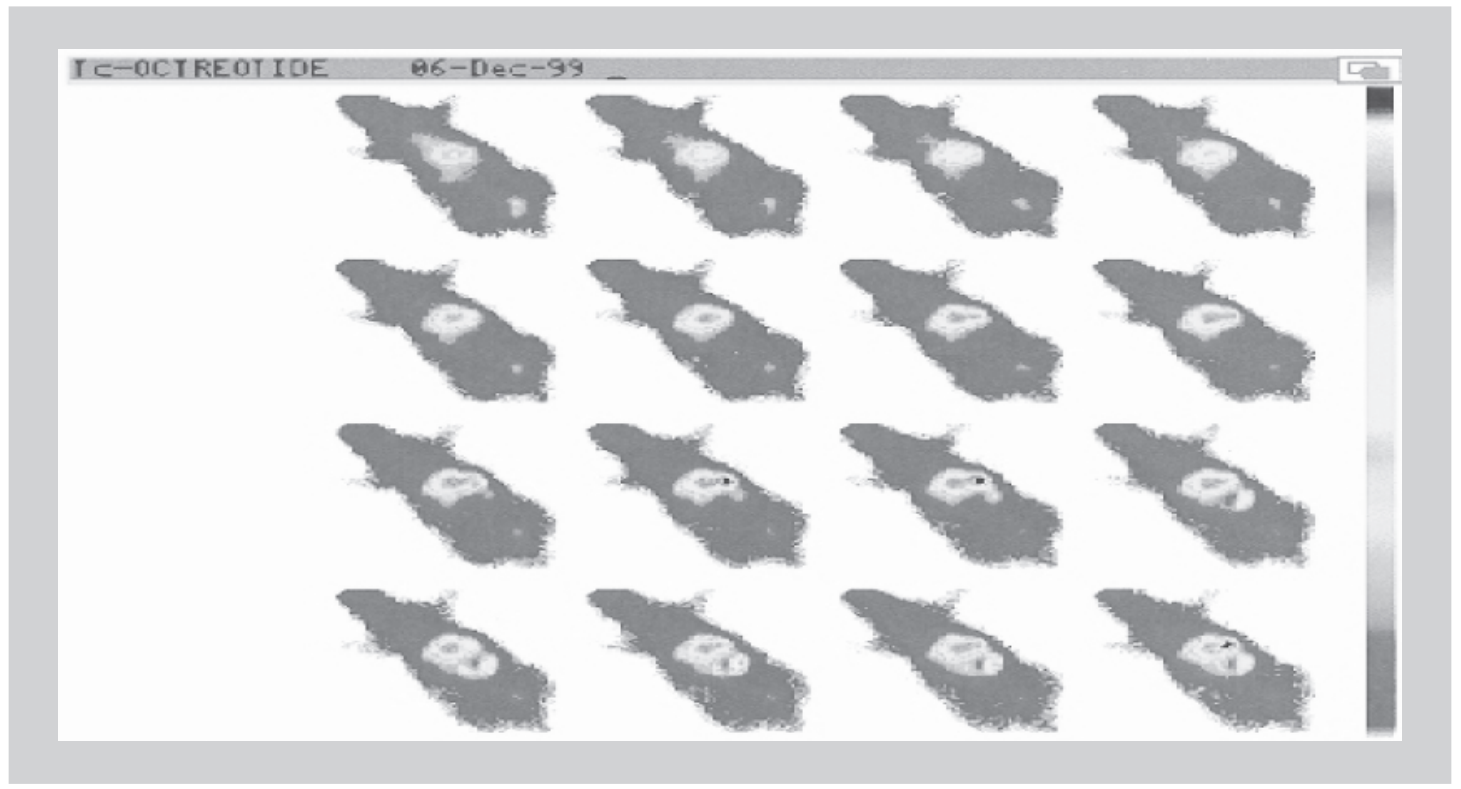

FIGURE 6 - Dynamic imaging of ${ }^{99 m}$ Tc-octreotide in the first 10 minutes. Acquisition time for each image was 37.5 seconds, and sequence was from left to right and from top to bottom line.

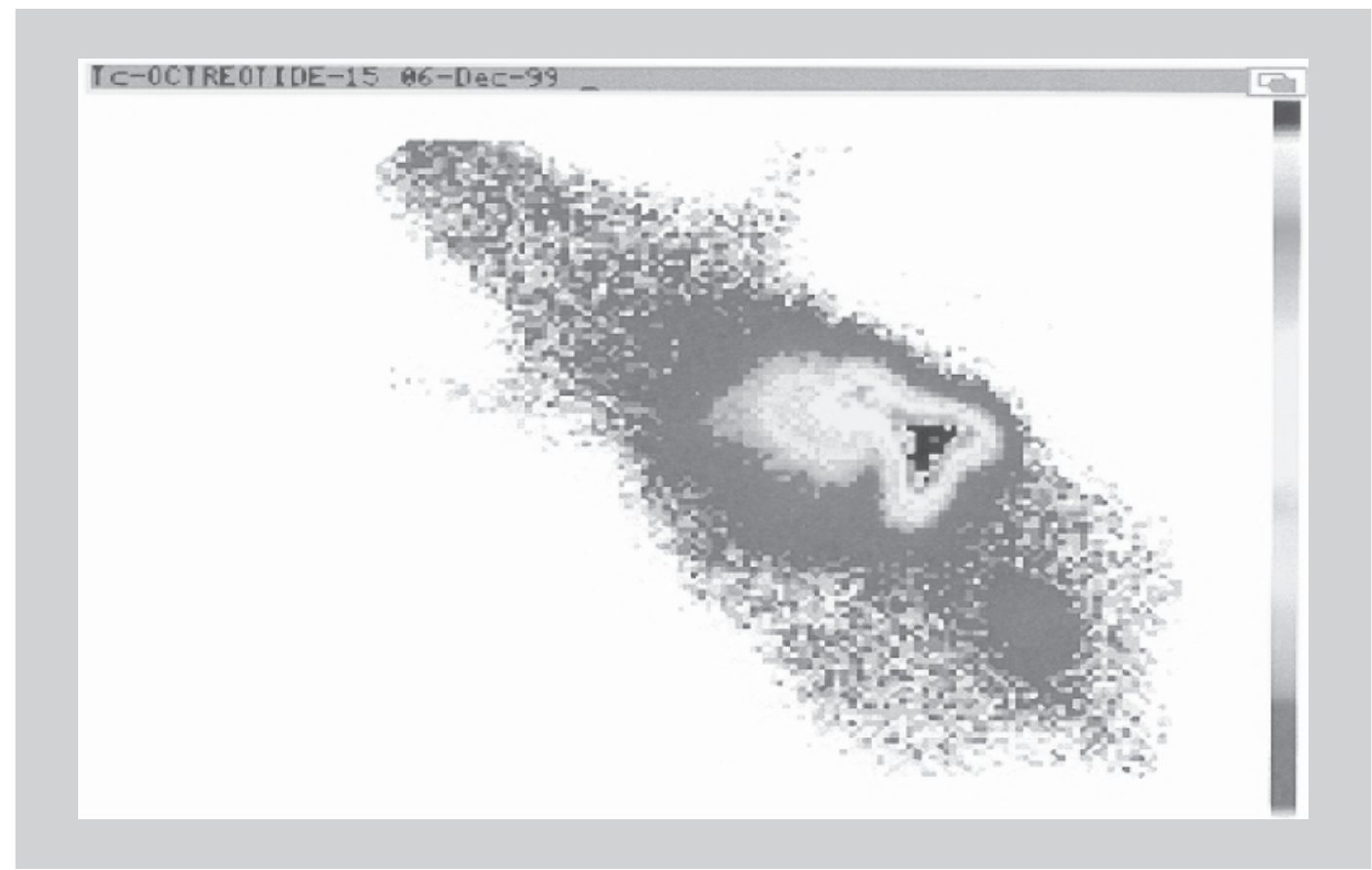

FIGURE 7 - Static imaging of ${ }^{99 m} \mathrm{Tc}$-octreotide at $15 \mathrm{~min}$ post-injection. 


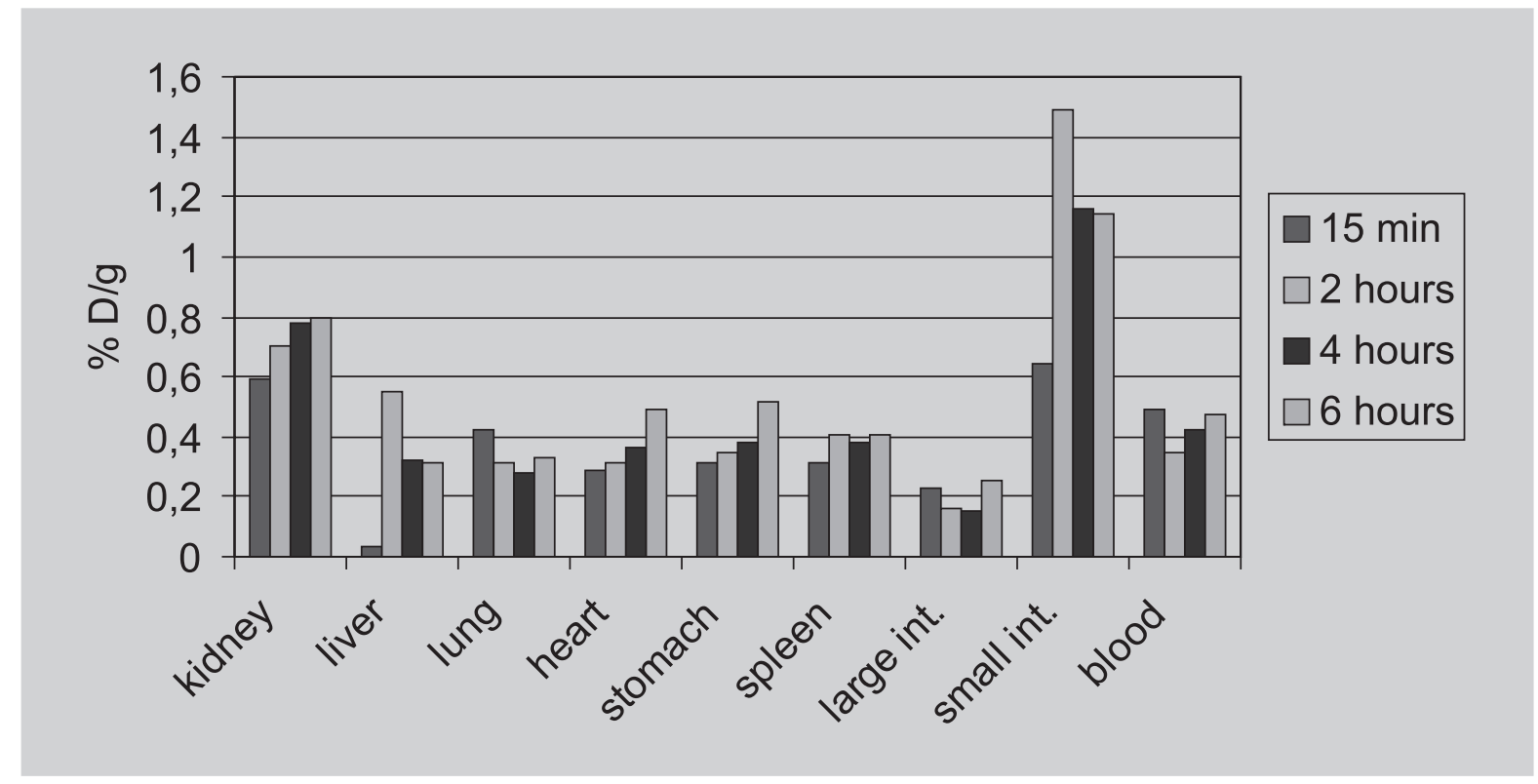

FIGURE 8 - Biodistribution of ${ }^{99 m}$ Tc-octreotide.

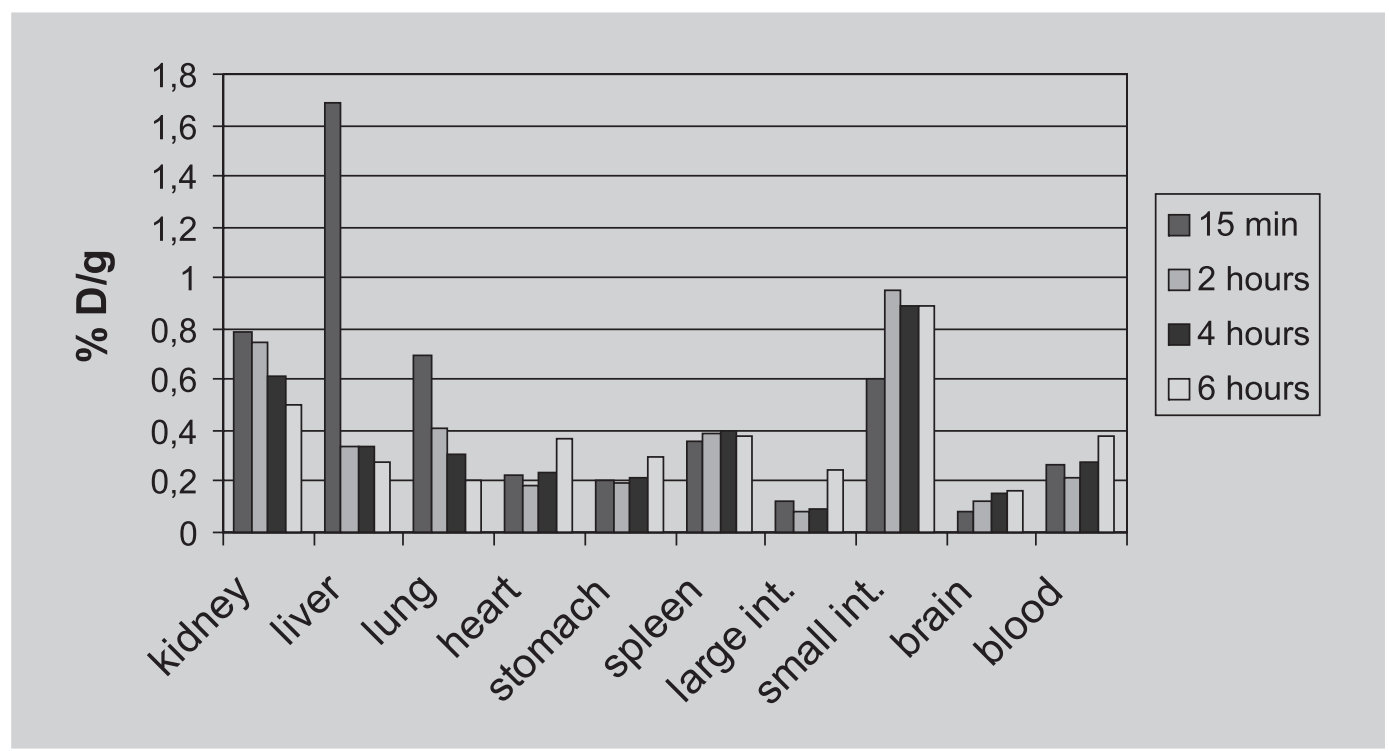

FIGURE 9 - Biodistribution of ${ }^{99 \mathrm{~m}} \mathrm{Tc}-$ lanreotide.

could be detected during 6 hours (Figure 9). This was true for ${ }^{99 \mathrm{~m}} \mathrm{Tc}$-octreotide as well (Figure 8). Other organs involved in uptake or clearance were kidneys, small intestine and lungs.

\section{DISCUSSION}

Somatostatin analogues, namely octreotide, lanreotide and others, were developed because the native peptide is susceptible to very rapid enzymatic degradation.
The major challenge to label peptides with ${ }^{99 \mathrm{~m}} \mathrm{Tc}$ is to obtain a product that doesn't loose receptor binding affinity or specificity. The peptide must be designed to be resistant to proteases.

Labeling can be done by direct method when cyclized peptide molecules are employed, based upon the reduction of disulfide bridge. The indirect method depends on a bifunctional chelating agent which is chemically coupled to the terminal amino groups of (D) phenylalanine. During this procedure, other functional 
groups are blocked and then deblocked. Often after radiolabeling the radiopharmaceutical must be purified. The steps require time and additional cost.

The direct method is a simple procedure since it eliminates the need for peptide conjugation with an exogenous chelator (Thakur et al., 1996).

Although it is considered necessary to use cyclized cisteine for the direct labeling method, and that cyclization confers resistance to proteolysis, the reduction of the cysteine bridge can inactivate the peptide. But, studies done with octreotide and with RC-160 with ${ }^{99 \mathrm{~m}} \mathrm{Tc}$ and ${ }^{186} \mathrm{Re}$ have not shown any apparent loss of biological activity (Haberberger et al., 1995) encouraging the use of this method.

In the current protocol, radiochemical purity of ${ }^{99 m}$ Tc-peptides was strongly linked to molar ratio between reducing agent and peptide. The involvement of tin in protein labeling as a tin-protein intermediate was suggested by Rhodes (1991).For a pretinning procedure, the reduction of native disulfide bridges is carried out by incubating the protein with stannous ions. Technetium$99 \mathrm{~m}$ available in the $7+$ oxidation state as ${ }^{99} \mathrm{mcO}_{4}{ }^{-}$must be reduced to a lower oxidation state, and that can be done using the same reducing agent, stannous chloride. In the procedure, as the thiol protecting group is removed, the mixture needs to be heated due to the slow labeling kinetics at room temperature (Okarvi, 1999).

Transchelation studies evaluated the bond strength of the ${ }^{99 \mathrm{~m}} \mathrm{Tc}$-peptide complexes upon the presence of cysteine in body. Maximum concentration of cysteine to which the peptide is expected to be exposed in vivo is 1 $\mathrm{mM}$ (Cooper, 1983). The high molar ratio demonstrated to cause displacement suggests that bond strength of the ${ }^{99 m}$ Tc-peptides was very high.

The highest rate of transchelation observed in our study, for ${ }^{99 \mathrm{~m}} \mathrm{Tc}$-lanreotide, was $13 \%$ at $100 \mathrm{mM}$ of cysteine, in comparison with $70 \%$ observed by Pervez et al., 2001, for the same concentration of cysteine.

In biodistribution studies it had been documented that main organ uptake by ${ }^{99 m} \mathrm{Tc}-$ lanreotide was liver, from where it was cleared to small intestine, whereas for ${ }^{99 \mathrm{~m}} \mathrm{Tc}-$ octreotide small intestine came first, followed by clearance to kidneys. The difference between both complexes is due to different structures (amino acid sequence) that influence lipophilicity and biodistribution.

Blood values remained unaltered (approximately $0.5 \% \mathrm{ID} / \mathrm{mL}$ ) during 6 hours post injection (p.i.); similar to the findings obtained for ${ }^{99 \mathrm{~m}} \mathrm{Tc}$-sandostatin $0.3 \% \mathrm{ID} /$ mL, 24 hours p.i., by Kolan et al. (1996).

In addition to lipophilicity, stability of the complex also seems to be an important factor influencing biodistribution. Lanreotide is more lipophilic than octreotide and is very similar to another fully studied agent, vapreotide (RC-160), with differences in the extremes of the molecule.

\section{CONCLUSION}

Labeling of both peptides with ${ }^{99 \mathrm{~m}} \mathrm{Tc}$ by direct method was simple and efficient, with a high labeling yield, stability in face of cysteine challenge, and an interesting biodistribution pattern. Lanreotide and Octreotide are cyclic octapeptide analogues of somatostatin that were labeled with the radioisotope technetium-99m for future use in diagnostic nuclear medicine. The peptides were processed in a tartrate/ phthalate buffer solution containing reducing agent. The purpose of this investigation was to optimize direct labeling by varying some parameters, and to evaluate radiochemical stability and biodistribution in animals. The marked peptides were obtained with high labeling efficiency and no need for subsequent purification. Best radiolabeling results corresponded to a molar ratio of $\mathrm{SnCl}_{2} \cdot \mathrm{H}_{2} \mathrm{O} /$ peptide of 4.5 . ${ }^{99 \mathrm{~m}} \mathrm{Tc}$-peptides were radiochemically stable for 6 hours. ${ }^{99 \mathrm{~m}} \mathrm{Tc}$-octreotide was relatively more susceptible to cysteine challenge than ${ }^{99 \mathrm{~m}} \mathrm{Tc}$-lanreotide. ${ }^{99 \mathrm{~m}} \mathrm{Tc}-$ peptides were mainly distributed in the gastrointestinal tract but ${ }^{99 \mathrm{~m}} \mathrm{Tc}$-lanreotide showed a greater uptake by the liver than ${ }^{99 \mathrm{~m}} \mathrm{Tc}$-octreotide. Results indicated that the products can be obtained with high radiochemical yield, in a simple routine appropriate for further studies to assess their efficacy in radiodiagnosis.

\section{ACKNOWLEDGMENTS}

Support from the Co-ordinated Project of the International Atomic Energy Agency (IAEA): "Development of labeled biomolecules for targeted radiotherapy" is acknowledged.

\section{RESUMO}

\section{Lanreotídeo e octreotídeo complexados com tecnécio-99m: estudo de marcação estabilidade e estudos de biodistribuição}

Lanreotídeo e octreotídeo são octapeptídeos cíclicos análogos da somatostatina e têm sido marcados com Tecnécio-99m para uso em diagnóstico na Medicina $\mathrm{Nu}$ clear. Os peptídeos são preparados em solução tampão ftalato/tartarato contendo um agente redutor. O objetivo deste estudo foi a otimização da marcação direta variando 
alguns parâmetros e a avaliação da estabilidade radioquímica e biodistribuição em animais. Os peptídeos marcados foram obtidos com alta eficiência de marcação e sem a necessidade de etapa de purificação no final do processo. Os melhores resultados de radiomarcação corresponderam á razão molar de $\mathrm{SnCl} \mathrm{Cl}_{2} 2 \mathrm{H}_{2} \mathrm{O}$ /peptídeo de 4,5. Os peptídeos ${ }^{99 m} \mathrm{Tc}$ mostraram-se radioquimicamente estáveis por 6 horas. Octreotídeo- ${ }^{99 m} T c$ mostrou-se relativamente mais suscetivel frente à cisteina do que o lanreotídeo- ${ }^{99 m} T c$. Os peptídeos $-{ }^{99 m}$ Tc foram principalmente distribuidos no trato gastrointestinal, porém o lanreotídeo- ${ }^{99 m}$ Tc mostrou maior captação pelo figado do que o octreotídeo- ${ }^{99 m} \mathrm{Tc}$. Os resultados indicaram que os produtos podem ser obtidos com alto rendimento radioquímico e com procedimento simples, permitindo estudos posteriores para avaliação de sua eficácia em radiodiagnóstico.

UNITERMOS: Tecnécio-99m. Radiomarcação. Peptídeos. Somatostatina. Octreotídeo. Lanreotídeo.

\section{REFERENCES}

ANGELETTI, S; CORLETO, V.D; SCHILLACI, O; MARIGNANI, M.; ANNIBALE, B.; MORETTI, A.; SILECCHIA, G.; SCOPINARO, F.; BASSO, N.; BORDI, C.; DELLE FAVE, G. Use of the somatostatin analogue octreotide to localise and manage somatostatinproducing tumours. Gut, v. 42, p. 792-794, 1998.

ARNOLD, R.; SIMON, B.; WIED, M. Treatment of neuroendocrine GEP tumours with somatostatin analogues: a review. Digestion, v. 62, supl. 1, p. 84-91, 2000 .

BAIDOO, K. E.; LIN, K. S.; ZHAN, Y.; FINELY, P.; SCHEFFEL, U.; WAGNER JUNIOR, H. N. Design, synthesis, and initial evaluation of high-affinity technetium bombesin analogues. Bioconj. Chem., v. 9, p. 218-225, 1998.

COOPER, A. J. L. Biochemistry of sulfur-containing amino acids. Ann. Rev. Biochem., v. 52, p. 187-222, 1983.

HABERBERGER, T.; ZAMORA, P.; HOSONO, M. Initial studies on ${ }^{99 \mathrm{~m}} \mathrm{Tc}$ - and ${ }^{188} \mathrm{Re}$-somatostatin analogues stannous mediated direct-labeling and biodistribution in mice. In: NICOLINI M., BANOLI G., MAZZI,U., eds. Technetium and Rhenium in Chemistry and Nuclear Medicine. Padova: SG Editorial, 1995. p. 367-371.
HNATOWICH, D. J; QU, T.; CHANG, F.; LEY, A. C; LANDER, R. C; RUSCKOWSKI, M. Labeling peptides with technetium-99m using a bifuncional chelator of a Nhydroxysuccinimide ester of mercaptoacetyltriglycine. $J$. Nucl. Med., v. 39, p. 56-64, 1998.

KOLAN, H.; LI, J.; THAKUR, M. L. Sandostatin labelled with Tc: in vitro stability, in vivo validity and comparison with 111In-DTPA-octreotide. Pept. Res., v. 9, p. 144-146, 1996.

KRENNING, E. P; BAKKER, W. H; KOOIJ, P. P; BREEMAN, W. A; OEI, H. Y; DE JONG, M; REUBI, J. C; VISSER, T. J; BRUNS, C; KWEKKEBOOM, D. J. Somatostatin receptor scintigraphy with indium-111DTPA-D-Phe-1-octreotide in man: metabolism, dosimetry and comparison with iodine-123-tyr-3octreotide. J. Nucl. Med., v. 33, p. 652-658, 1992.

LAMBERTS, S. W. J; BAKKER, W. H.; REUBI, J. C.; KRENNING, E. P. Somatostatin receptor imaging in the localization of endocrine tumours. N. Engl. J. Med. v. 323 , p. 1246-1249, 1990.

LENERS, N.; JAMAR, F.; FIASSE, R.; FERRANT, A.; PAUWELS, S. Indium-111-pentetreotide uptake in endocrine tumors and lymphoma. J. Nucl. Med. v. 37, p. 916-922, 1996.

OKARVI, S. M. Recent developments in ${ }^{99 \mathrm{~m}} \mathrm{Tc}-$ labelled peptide-based radiopharmaceuticals: An overview. Nucl. Med. Commun., v. 20, p. 1093-1112, 1999.

OPPIZZI, G.; COZZI, R.; DALLANBONZANA, D.; ORLANDI, P.; BENINI, Z.; PETRONCINI, M.; ATTANASIO, R.; MILELLA, M.; BANFI, G.; POSSA, $M$. Scintigraphic imaging of pituitary adenomas: na in vivo evaluation of somatostatin receptors. J. Endocrinol. Inves., v. 21, p. 512-519, 1998.

PERVEZ, S.; MUSHTAQ, A.; ARIF, M. Technetium-99m direct radiolabeling of Lanreotide: a somatostatin analog. Appl. Radiat. Isot., v. 55, p. 647-651, 2001.

RENNEN, H. J.; BOERMAN, O. C.; OYEN, W. J.; VAN DER MEER, J. W.; CORSTENS, F. H. Specific and rapid scintigraphic detection of infection with ${ }^{99 \mathrm{~m} T \mathrm{Tc}-l a b e l e d}$ interleukin-8. J. Nucl. Med., v. 42, p. 117-123, 2001.

RHODES, B. A. Direct labeling of proteins with ${ }^{99 \mathrm{~m}} \mathrm{Tc}$. Nucl. Med. Biol., v. 18, 667-676, 1991. 
RHODES, B. A.; ZAMORA, P. O.; MAREK, M. J.; SHARMA, S. D.; WALL, F. J. Direct 99mTc-labelling of proteins and peptides: factors that alter radiochemical yields and in vivo stability. In: NICOLINI, M.; BANOLI, G.; MAZZI, U., eds. Technetium and Rhenium in Chemistry and Nuclear Medicine. Padova: SG Editorial, 1995. p. 281-286.

SIGNORE, A., PROCACCINI, E., CHIANELLI, M., SALERNO, G., IOZZO, P., ANNOVAZZI, A., LEONETTI, F., TAMBURRANO, G., RONGA, G. SPECT imaging with 111 In-octreotide for the localization of pancreatic insulinoma. Quart. J. Nuclear Med., v. 39, supl. 1, p. 111-112, 1995.

SMITH-JONES, P. M.; BISCHOF, C.; LEIMER, M.; GLUDOVACZ, D.; ANGELBERGER, P.; PANGERL, T.; PECK-RADOSAVLJEVIC, M.; HAMILTON, G.; KASERER, K.; KOFLER, A.; SCHLENGBAUERWADL, H.; TRAUB, T.; VIRGOLINI, I. DOTAlanreotide: A novel somatostatin analog for tumor diagnosis and therapy. Endocrinology, v. 140, p. 51365148, 1999.
THAKUR, M. L.; KOLAN, H. R.; RIFAT, S.; LI, J.; RUX, A.; JOHN, E.; HALMO, G.; SCHALLY, A.V. Vapreotide labeled Tc-99m for imaging tumors: Preparation and preliminary evaluation. Int. J. Oncol., v. 9, p. 445-451, 1996.

VAN DER LAKEN, C. J.; BOERMAN, O. C.; OYEN, W. J.; VAN DER VEM, M. T.; VAN DER MEER, J. W.; CORSTENS, F. H. Radiolabeled interleukin-8: specific scintigraphic detection of infection within a few hours. $J$. Nucl. Med., v. 41, p. 463-469, 2000.

WEINER, R. E.; THAKUR, M. L. Radiolabeled peptides in the diagnosis and therapy of oncological diseases. Appl. Radiat. Isot., v. 57, p. 747-749, 2002.

Recebido para publicação em 30 de abril de 2003. 